\title{
Simulation and Optimization of Photovoltaic/ Diesel Hybrid Power Generation Systems for Health Service Facilities in Rural Environments
}

\author{
Ani Vincent Anayochukwu ${ }^{1 *}$ Emetu Alice Nnene ${ }^{2}$ \\ 1 Department of Electronic Engineering, University of Nigeria, Nsukka, Nigeria. \\ 2 Department of Nutrition and Dietetics, University of Nigeria, Nsukka, Nigeria. \\ * Corresponding author: Email: vincent_ani@yahoo.com. Phone Number: \\ +2348054024629 .
}

ABSTRACT Hybrid photovoltaic (PV)/diesel power systems can be used to upgrade power generation systems in medical clinics to improve the delivery of local health services. This study presents the design of hybrid (PV/diesel) power systems for medical facilities in the Agbani district (Nkanu-West) in Eastern Nigeria with a daily load of $19 \mathrm{kWh} \mathrm{d}^{-1}$. Solar resources for the design of the system were obtained from the NASA Surface Meteorology and solar energy website at a location of $6^{\circ} 00^{\prime} \mathrm{N}$ latitude and $7^{\circ} 00^{\prime} \mathrm{E}$ longitude, with annual average solar radiation of 4.95 $\mathrm{kWh} \mathrm{m}{ }^{-2} \mathrm{~d}^{-1}$. The design is based on theoretical model of the power stations using Hybrid Optimization Model for Electric Renewables (HOMER) software. The model was designed to provide an optimal system configuration based on hour-by-hour data for energy availability and demands. Energy source, energy storage and their applicability in terms of performance are discussed. From the simulation results, it is shown that the designed hybrid PV/diesel system reduces the operational cost and quantity of air pollutants from a diesel-only system. Details of the comparisons are presented.
Received 16 February 2013; revision received 11 March 2013; accepted 19 March 2013. Published online 30 April 2013 (www.ejee.cl). DOI 10.7770/ejee-V1N1-art485.

๑) Renewable Energies Research Nucleus, UC Temuco.

KEYWORDS Hybrid system, power consumption, power supply, health clinic, HOMER.

\section{Introduction}

Electricity is an increasingly essential resource in remote health care facilities. Recent improvements in the distribution of vaccines and other cold chain dependant supplies, as well as the global push to deliver antiretroviral drugs and services to HIV-positive patients worldwide, introduce new demands for electricity in sites with little or no access to reliable electrical power. Refrigerators and electronic diagnostic tools are part of the standard of care in many rural clinics throughout the world. In rural health clinics, electric lighting provides public security, allows facilities to remain open in the evenings and supports limited surgical procedures (e.g. suturing). If a clinic is without lights, patients arriving at night must wait until morning to receive care. Beyond lighting, electricity is used to power an array of appliances (such as vaccine refrigerators and other medical supplies), and other specialized equipment (centrifuge, hematology mixer, microscope, incubator, and hand- 
Table 1 Health facility's energy needs.

\begin{tabular}{|llccccc|}
\hline S/no & Power Consumption & $\begin{array}{c}\text { Power } \\
\text { (Watts) }\end{array}$ & Qty & Load (watt x qt) & Hours/day & $\begin{array}{c}\text { On-Time (Time in } \\
\text { Use) }\end{array}$ \\
\hline 1 & Vaccine Refrigerator/Freezer & 60 & 1 & 60 & 24 & $(0.00 \mathrm{hr}-23.00 \mathrm{hr})$ \\
\hline 2 & Small Refrigerator (non-medical use) & 300 & 1 & 300 & 5 & $(10.00 \mathrm{hr}-15.00 \mathrm{hr})$ \\
\hline 3 & Centrifuge & 575 & 1 & 575 & 2 & $(12.0 \mathrm{hr}-14.00 \mathrm{hr})$ \\
\hline 4 & Hematology Mixer & 28 & 1 & 28 & 2 & $(10.00 \mathrm{hr}-12.00 \mathrm{hr})$ \\
\hline 5 & Microscope & 15 & 1 & 15 & 5 & $(09.00 \mathrm{hr}-14.00 \mathrm{hr})$ \\
\hline 6 & Security light & 10 & 4 & 40 & 12 & $(18.00 \mathrm{hr}-6.00 \mathrm{hr})$ \\
\hline 7 & Lighting & 10 & 2 & 20 & 7 & $(09.00 \mathrm{hr}-16.00 \mathrm{hr})$ \\
\hline 8 & Sterilizer Oven (Laboratory Autoclave) & 1,564 & 1 & 1,564 & 1 & $(12.00 \mathrm{hr}-13.00 \mathrm{hr})$ \\
\hline 9 & Incubator & 400 & 1 & 400 & 24 & $(0.00 \mathrm{hr}-23.00 \mathrm{hr})$ \\
\hline 10 & Water Bath & 1,000 & 1 & 1,000 & 1 & $(14.00 \mathrm{hr}-15.00 \mathrm{hr})$ \\
\hline & Communication via VHF Radio & & 1 & & & \\
\hline 11 & Stand-by & 2 & & 2 & 24 & $(0.00 \mathrm{hr}-23.00 \mathrm{hr})$ \\
\hline 12 & Transmitting & 30 & & 30 & 4 & $(09.00 \mathrm{hr}-13.00 \mathrm{hr})$ \\
\hline 13 & Desktop Computer & 200 & 2 & 400 & 5 & $(09.00 \mathrm{hr}-14.00 \mathrm{hr})$ \\
\hline 14 & Printer & 65 & 1 & 65 & 3 & $(09.00 \mathrm{hr}-10.00 \mathrm{hr} ;$ \\
& & & & & & $13.00-15.00 \mathrm{hr})$ \\
\hline
\end{tabular}

powered aspirator). Access to electricity is vital to community service facilities in rural areas. Health service facilities without a connection to the national or local electricity grid must rely on alternative energy sources (e.g., independent diesel generators, solar photovoltaic (PV) systems, liquefied petroleum gas (LPG) or kerosene), or do without.

In many developing countries, rural electrification rates are low, and most community health facilities lack access to electricity. Nigeria is a typical example. In rural areas, where more than 80 percent of the country's 167 million [Population census, 2012] people live, most health facilities lack electricity. Selecting appropriate sources of reliable, sustainable energy can help mitigate the challenges of operating Elath facilities in Nigeria.
Overview of the study area - problem statement

The Health Service Facility under study is is a clinic located in a remote setting of the Agbani District in Nkanu-West, local government area of Enugu State, Nigeria. The clinic is not connected to the grid, and currently utilizes a diesel generator to partially meet its energy needs. Although the facility possesses a large generator, it is often in disuse because of the money required to use the generator. It is incresingly necessary that a reliable, alternative energy source is determined for this, and other rural clinics, which are crucial in the delivery of life-saving medicines.

\section{Power consumption}

Health clinics offers an array of services, including the treatment of illnesses, tending of injuries and provision of basic immunization services. Rural health 
Table 2 The electrical load (daily load demands) data for a health facility.

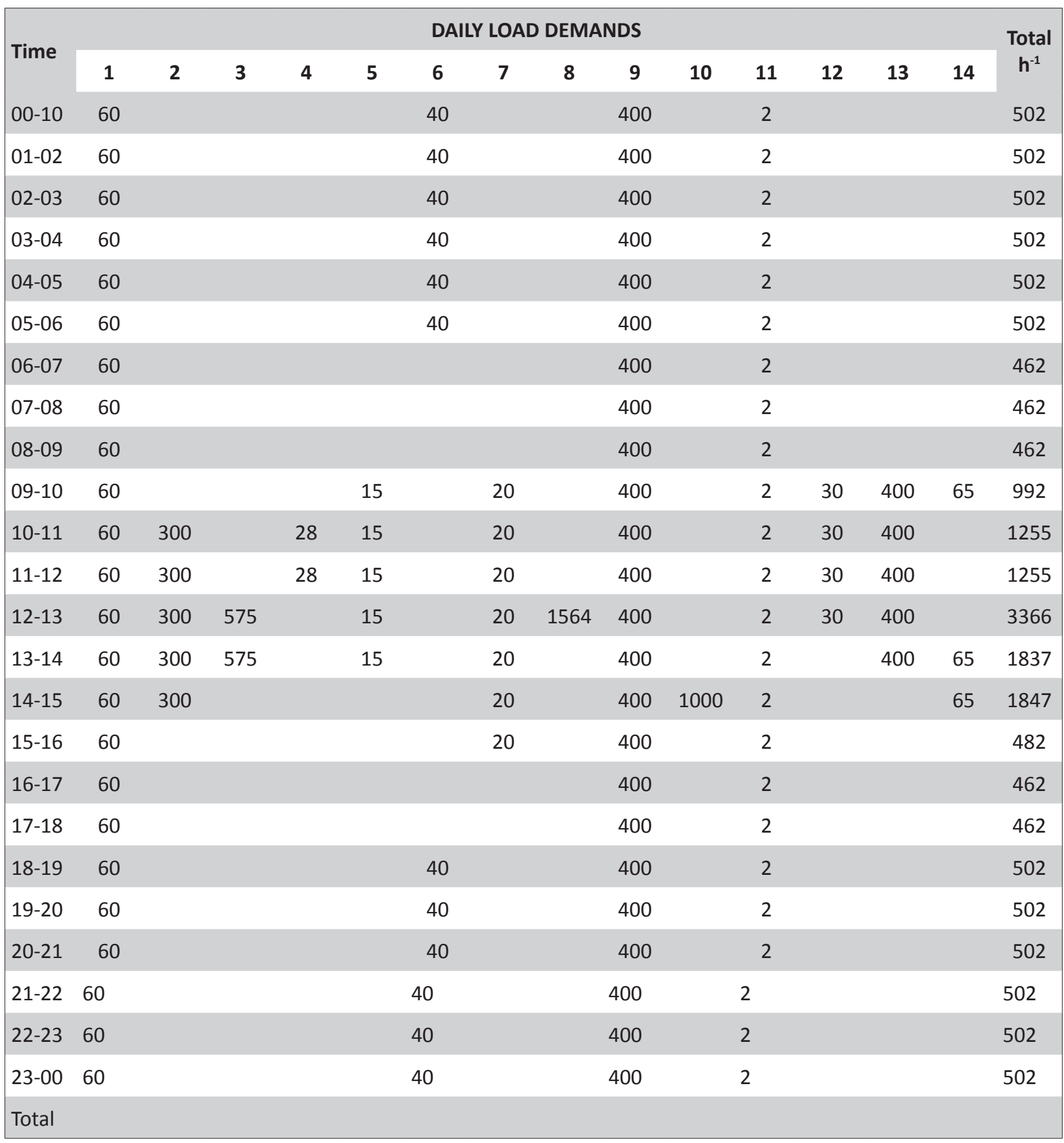

clinics possess sophisticated diagnostic equipment that requires a reliable power supply. The energy demand is based on the type and number of medical devices used in the facility, and the frequency with which they are used.

From the data acquired from the Agbani health clinic, a profile of the health service facility was created and it is shown in Tables 1 and 2.
The daily average load variation is shown in Fig. 1 and tabulated in Table 2; it is assumed that it is identical for every day of the year. The annual peak load of $3.4 \mathrm{~kW}$ was observed between 12:00 $\mathrm{h}$ and 13:00 h, with $19 \mathrm{kWh} \mathrm{d}^{-1}$ energy consumption. 


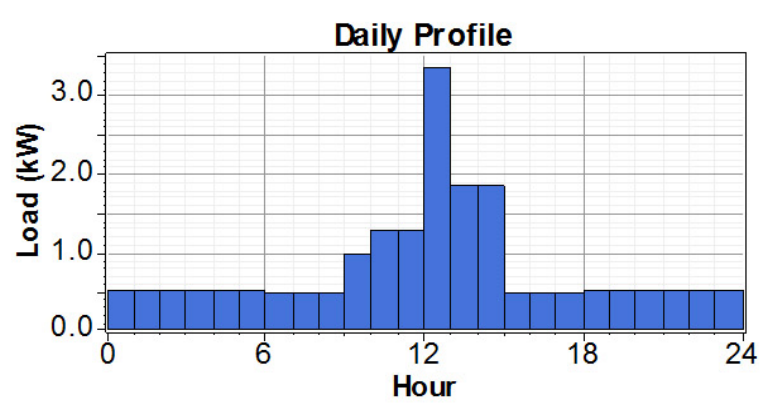

Figure 1 Daily average load variation for a health facility.

\section{Hybrid power systems (HPS)}

A hybrid powered system can be described as an electricity production system which consists of a combination of two or more types of electricity generating sources (e.g. solar photovoltaic panels, wind turbine generators, pico-hydro plants, and/or fuel generators) [Ani and Emetu, 2013]. The useful components of hybrid systems considered in this study are solar photovoltaic panels and wind turbine generators. A diesel generator can provide energy at any time, whereas energy from PV and wind is greatly dependent on the availability of solar radiation and wind speed, respectively [Wichert, 1997; Yu et al., 2005]. This makes the system (generator) more reliable, and can be used to operate when PV and/or wind fail to satisfy the load, or when the battery storage is depleted.

A hybrid system uses advanced system control logic (also known as a dispatch strategy) to coordinate when power should be generated by renewable energy and when it should be generated by sources like diesel generators [Ani and Emetu, 2013]. The real innovation of hybrid power generation is in closely matching the cheapest energy production with the load. Important in understanding this process is the realization that cost savings do not come from using the most powerful solar panels or the most efficient diesel engine, but from the refinement of this "matching" process. By coupling and coordinating sources together, the system provides more reliable and higher quality electricity at lower costs [Faruk et al., 2012]. For the hybrid power system, a diesel generator was used, hybridized with a PV system. The details of the power generating set and the weather conditions of Agbani are used as input data for the simulation software used for this study.

The aim of this study is to determine the suitability of hybrid PV/diesel systems in order to upgrade health clinic power generation systems, which would improve the delivery of local health care services.

\section{Renewable energy sources}

\section{Photovoltaic energy}

Nigeria is a tropical country situated in the West African region and lies between longitudes 3 degrees and 14 degrees and latitudes 4 degrees and 14 degrees [Nigerian Geography, 2013] with landmass of $9.24 \times 105 \mathrm{~km}^{2}$. Nigeria enjoys average daily sunshine of $6.25 \mathrm{~h}$; ranging between about $3.5 \mathrm{~h}$ in coastal areas and $9.0 \mathrm{~h}$ at the far northern boundary [Bala et al., 2000]. Its climate varies from tropical to subtropical. There are two main seasons; the dry season lasting from October to March, and the rainy season lasting from April to October. In the north, it is hot and dry, and the rainy season extends from April to September. In the south, it is hot and wet, with the rainy season extending between March and December. From December to March there is a long dry season [Ojo, 2000]. Temperatures at the coast rarely rise above $32^{\circ} \mathrm{C}$. The north is drier with temperature range between $32^{\circ} \mathrm{C}$ and $42^{\circ} \mathrm{C}$. Humidity is about $95 \%$ [Falade, 1995]. The terrestrial radiation on Nigeria's land area is $2.079 \times 1015 \mathrm{kWh}$ year ${ }^{-1}$. Solar energy is one of the in-exhaustible energy sources available for the implementation of renewable energy systems for health clinics in Nigeria. Therefore, integration of solar photovoltaic energy with a readily available standalone diesel generator (or generally known as the hybrid $\mathrm{PV} /$ diesel system) has a strong potential application in health care.

\section{Wind resource}

Wind speed is relatively weak in the study area, with an average of $2.1 \mathrm{~m} \mathrm{~s}^{-1}$ throughout the year. This shows that wind resource is extremely low at this site, 


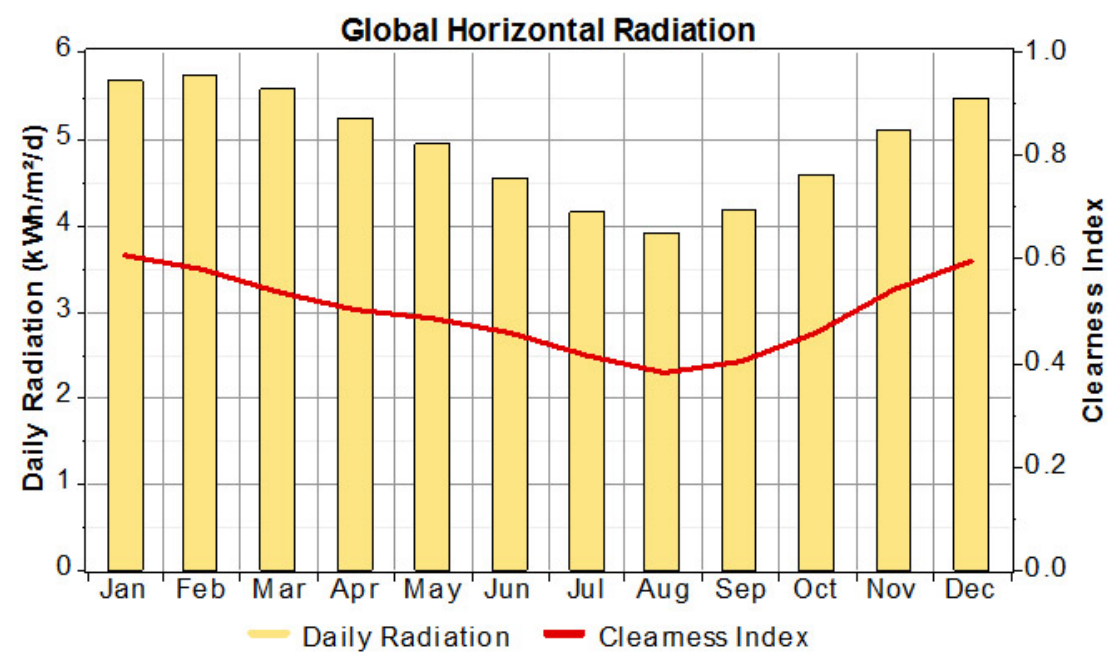

Figure 2 HOMER output graphic for solar radiation profile for Agbani in Nkanu-West (Enugu State).

and therefore this investigation will not include a wind turbine option.

\section{Energy resources}

For this study, only solar renewable energy resources were considered. The data for the solar (clearness index and radiation) resource was obtained from the NASA Surface Meteorology and Solar Energy web site [NASA, 2010] in Agbani of Nkanu-West (Enugu State) at a location of $6^{\circ} 00^{\prime} \mathrm{N}$ latitude and $7^{\circ} 00^{\prime}$ E longitude with annual average solar (daily average radiation) of $4.925 \mathrm{kWh} \mathrm{m}^{-2} \mathrm{~d}^{-1}$. Fig. 2 shows the solar resource profile for Agbani in Nkanu-West, and is tabulated in Table 3.

\section{Solar radiation variation}

February is the sunniest month of the year, at which time solar energy resource is $5.7 \mathrm{kWh} \mathrm{m}^{-1} \mathrm{~d}^{-1}$, while in August it drops to $3.9 \mathrm{kWh} \mathrm{m}^{-2} \mathrm{~d}^{-1}$ as shown in Fig. 2 and Table 3.

In the months of September, October, November, December, January, and February, the solar radiation increases with differences from month to month as (0.28), (0.38), (0.54), (0.35), (0.22), and (0.06) respectively. Whereas in the months of March, April, May,
Table 3 Solar Resources for Agbani in Nkanu-West (Enugu State).

\begin{tabular}{|lcc|}
\hline Month & $\begin{array}{c}\text { Clearness } \\
\text { Index }\end{array}$ & $\begin{array}{c}\text { Average Radiation } \\
\text { (kWh } \mathbf{~ m}^{-2} \mathbf{~ d}^{-1} \text { ) }\end{array}$ \\
\hline Jan & 0.605 & 5.680 \\
Feb & 0.578 & 5.740 \\
Aar & 0.537 & 5.570 \\
May & 0.503 & 5.250 \\
Jun & 0.487 & 4.940 \\
Jul & 0.458 & 4.540 \\
Aug & 0.415 & 4.140 \\
Sep & 0.382 & 3.910 \\
Oct & 0.406 & 4.190 \\
Nov & 0.457 & 4.570 \\
Dec & 0.539 & 5.110 \\
Scaled annual & 0.595 & 5.460 \\
average & & 4.925 \\
\hline
\end{tabular}

June, July, and August, the solar radiation decreases with differences from month to month as (0.17), (0.32), (0.31), (0.4), (0.4), and (0.23) respectively. In these months, the diesel generator can compensate. 


\section{Design and simulation}

Numerous papers have been written about the optimum economic design of PV/diesel systems with energy storage in batteries. Wies et al. [2005] presented a simulation work, using Simulink, of a real hybrid PV-Diesel-Battery system located in Alaska, comparing it with a diesel-only (generator) system,, and another diesel-battery system to supply energy for the same load. Contaminating emissions were evaluated $\left(\mathrm{CO}_{2}, \mathrm{NO}_{\mathrm{X}}\right.$ and particles) for the various cases, comparing the results with those obtained by means of HOMER [HOMER, 2012] software. Additionally, the global efficiency of the system and its costs were determined. The results obtained indicate that the system with only a diesel generator had a lower installation cost, but higher operation and maintenance cost. Additionally, it was less efficient, and released more contaminating emissions than the PV-diesel-battery system.

[Shaahid and El-Amin, 2009] used HOMER to perform a techno-economic evaluation of PV/diesel/battery systems for rural electricity generation in Saudi Arabia. They examined the effect of the increase in PV/battery on the cost of energy (COE), operational hours of diesel generators and reduction in GHG emissions. Usually, the optimum design is carried out minimizing the Net Present Cost (NPC: investment costs plus the discounted present values of all future costs during the lifetime of the system) or by minimizing the Levelized Cost of Energy (LCE: total cost of the entire hybrid system divided by the energy supplied by the hybrid system).

Karakoulidis et al. [2011] developed a hybrid renewable energy technology (RET) model combining solar-photovoltaic (SPV), diesel generator (DG) and batteries to meet the load demand of an electric machinery laboratory in Kavala, Greece. Hybrid Optimization Model for Electric Renewable (HOMER) software was used for the optimization and simulation of different combinations and the best suited configuration was selected based on the Net Present Cost NPC. Giatrakos et al. [2009] created a sustainable renewable energy (RE) based system comprising wind energy, Solar-Photovoltaic (SPV) and a hydrogen system to replace the existing DG's in the Greek island Karpathos. HOMER was used for system design and planning analysis. With the help of historic data available for both supply and demand it was concluded that an RET system can penetrate up to $20 \%$ in the present electric energy mix.

\section{Design of the hybrid system}

Designing a hybrid system requires correct components selection and sizing with appropriate operational strategy [Borowy and Salameh, 1994; Dufo-López and Bernal-Agustín, 2005]. The design and operational control [Ashari and Nayar, 1999] is not a linear problem due to non-linear component characteristics with a large number of variables [Seeling-Hochmuth, 1998]. Simulation programs are the most common tools for optimal design of these systems. By using computer simulation, the optimum configuration can be found by comparing the performance and energy production cost of different system configurations. There are some programs that simulate hybrid systems, as HYBRID2 and HOMER. HYBRID2 simulates hybrid systems with very high precision calculations, but it does not optimize the system. HOMER simulates and optimizes the system. There are other simulation and optimization software tools, and some of them are free. A review of these software can be found in José et al. [2009].

\section{Choice of the software}

Among the two available software considered, HOMER was chosen. It is a user friendly software that can be easily configured, and the managed information is complete, as well. This software is a computer modelling tool based on a genetic algorithm that can evaluate different situations to determine the system configuration that will provide acceptable reliability at the lowest lifecycle cost [Ani and Emetu, 2013]. In addition to sizing the components of the hybrid system, HOMER also does a comparison between two simple dispatch strategies. HOMER's two dispatch strategies are Load Following and Cycle Charging. 


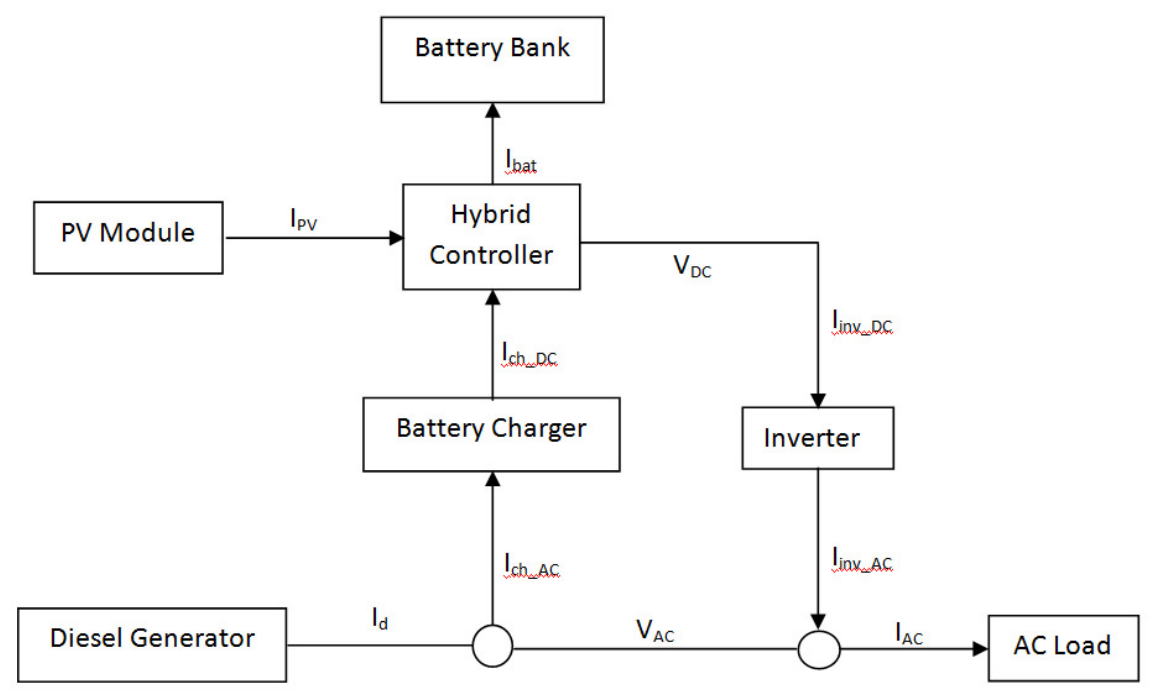

Figure 3 Proposed PV-Diesel Hybrid System.

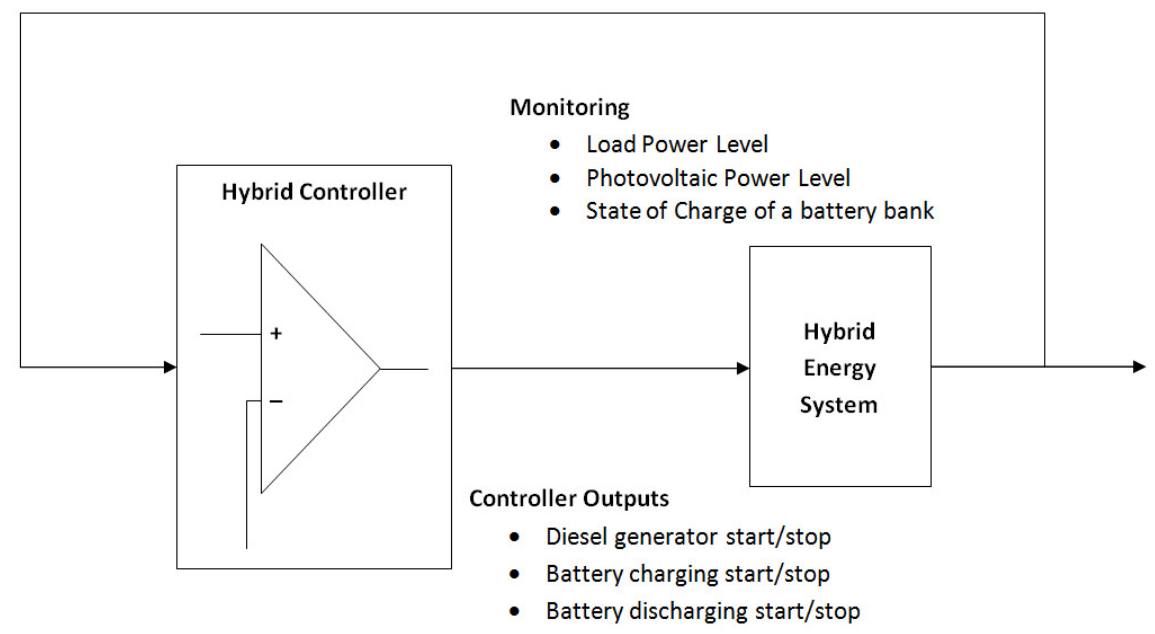

Figure 4 Hybrid system controller block diagram (Ani, 2013).

\section{Hybrid energy system configuration}

The hybrid system model described in this essay is the core of the simulation. Fig. 3 shows the proposed hybrid system set-up. Embedded power generation is defined as the interconnection of several distributed generators (PV panels and diesel generator) and a set of batteries. In this study, the hybrid energy system is based on a generalized three-bus configuration. The three buses are a DC bus, an AC bus, and a load bus.

Technology that generates DC current- PV and battery - are connected to the DC bus $\left(\mathrm{V}_{\mathrm{DC}}\right)$. Technology that generates $\mathrm{AC}$ current, i.e. diesel generators, are connected to the $\mathrm{AC}$ bus $\left(\mathrm{V}_{\mathrm{AC}}\right)$. Only $\mathrm{AC}$ appliances are used and are connected to the load bus $\left(\mathrm{I}_{\mathrm{AC}}\right)$. A battery charger is used to convert $\mathrm{AC}\left(\mathrm{I}_{\mathrm{ch} \_\mathrm{AC}}\right)$ current from diesel generator to $\mathrm{DC}\left(\mathrm{I}_{\mathrm{ch} \_\mathrm{DC}}\right)$ current to charge the battery and serve the load. An inverter, or a DC-to-AC converter, is used to convert DC current ( $\mathrm{I}_{\text {inv_DC }}$ ) to AC current ( $\mathrm{I}_{\text {inv_AC }}$ ) (from the DC bus to serve the AC load).

A Hybrid Controller shown in Fig. 4 is used to coordinate when power should be generated by renewable energy (PV panels) and when it should be generated by the diesel generator. It also controls the charge and discharge current from the battery. 


\section{Hybrid system controller}

An operational control strategy consists of certain predetermined control settings that are configured when installing the system, as shown in Fig. 4.

\section{Configuration of the stand-alone energy system}

The design of a stand-alone hybrid system is sitespecific and depends on both the resources available and the load demand [Ani and Nzeako, 2002]. A typical stand-alone hybrid diesel-solar PV system has an electricity generation device equipped with the wiring setup and supporting structures, as well as the necessary BOS components (i.e., the battery bank, the charging controller and the converter) [Kamaruzzaman et al., 2009]. The energy system proposed for the Health facility consists of solar PV and diesel power as depicted in Fig. 5.

The energy consumption of the health service facility is $19 \mathrm{kWh} \mathrm{d}^{-1}$ with a $3.4 \mathrm{~kW}$ peak demand load, and the proposed energy system (diesel/PV hybrid) consists of a $2.5 \mathrm{~kW}$ diesel generator, $5 \mathrm{~kW}$ solar PV array, 24 Surrette 6CS25P Battery Cycle Charging, and a $19 \mathrm{~kW}$ converter; whereas the existing system (diesel only) has a $2.5 \mathrm{~kW}$ diesel generator, 48 Surrette 6CS25P Battery Cycle Charging, and a $19 \mathrm{~kW}$ converter.

\section{Economics and constraints}

The project lifetime is estimated at 20 years. The annual interest rate is fixed at $6 \%$. There is no capacity shortage for the system and the operating reserve as a percentage of hourly load was $10 \%$. Meanwhile, the operating reserve as a percentage of solar power output was $25 \%$. Operating reserve is the safety margin that helps ensure reliability of the supply despite variability in electric load, and solar power supply.

\section{System economics}

The capital costs for all system components including PV module, diesel generator, rectifier, battery and ba-

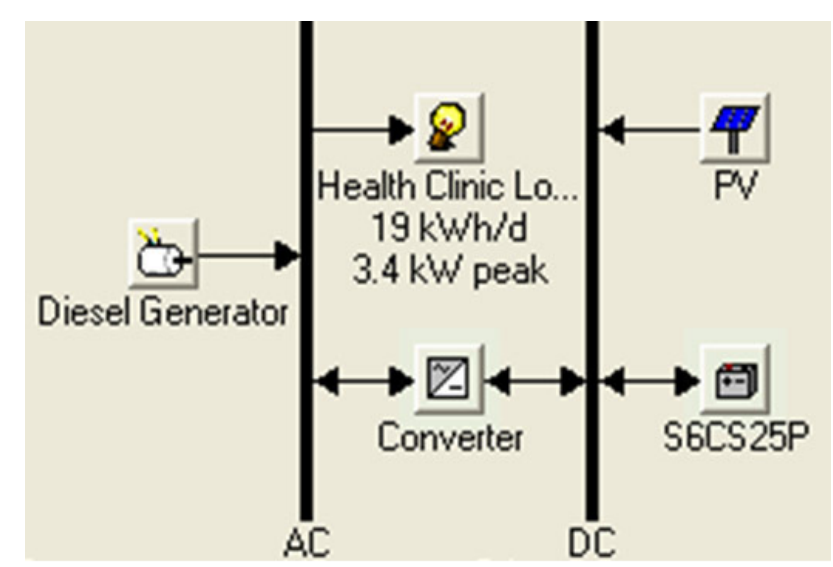

Figure 5 The network architecture for the HOMER simulator.

lance of system prices are based on quotes from PV system suppliers in Nigeria [Solarshopnigeria, 2012]. These costs are estimates based on a limited number of Internet enquiries and prices. They are likely to vary for the actual system quotes due to many market factors. The figures used in the analysis are therefore indicative.

The replacement costs of equipment are estimated to be $20 \%-30 \%$ lower than the initial costs, but because decommissioning and installation costs need to be added, it was assumed that they are the same as the initial costs. The PV array, diesel generator, rectifier and battery maintenance costs are estimates based on approximate time (20 yrs) required for the health facility. All initial costs including installation and commissioning, replacement costs and operating and maintenance costs at the health facility are summarized in Table 4. As HOMER calculates in US Dollar (\$), all costs have been converted from Naira (N) into USD (\$) as shown in Table 4 using the equivalent as N162 of Nigerian currency equal to 1US Dollar (\$) [Exchange rate, 2012]. Initially, the cost of system components was gotten in Naira from the local vendors and therefore changed to dollars before calculations. All costs presented are in US Dollar (\$).

\section{Simulation results}

The simulations provide information concerning the electricity production, economic costs and environmental characteristics of each system. The obtained 
Table 4 Summary of initial system costs, replacement costs and operating and maintenance costs.

\begin{tabular}{|lllll|}
\hline \multirow{2}{*}{ Parameter } & \multicolumn{2}{l}{ Existing system diesel only } & \multicolumn{2}{l|}{ Proposed hybrid diesel-solar PV system } \\
\cline { 2 - 3 } & Dollars(\$) & Naira(N) & Dollars(\$) & Naira(N) \\
Initial Cost & 63,760 & $10,329,120$ & 46,280 & $7,497,360$ \\
\hline Operating Cost & 30,254 & $4,901,148$ & 7,012 & $1,135,944$ \\
Total NPC & 410,769 & $66,544,578$ & 126,712 & $20,527,344$ \\
\hline
\end{tabular}

results are presented in Tables 5, 6, 7 and 8. The detailed analyses obtained at the end of the simulations are described below:

\section{Existing system:}

The existing system (diesel generator) has higher initial capital cost, higher operating cost and higher total net present cost for the whole project due to it has more number of batteries in its configuration than the hybrid PV/diesel system as shown in Fig. 6 and Table 5. Furthermore, this system emits more $\mathrm{CO}_{2}$ and $\mathrm{NO}_{\mathrm{X}}$ as a result of burning a lot of fossil fuel as shown in Table 7.

\section{Proposed hybrid system:}

A hybrid solar PV-diesel system can supply renewable energy, corresponding to $78 \%$ of the energy demand in the health facility as shown in Table 6. The hybrid solar PV-diesel system has less total net present cost as a result of less fuel consumption as shown in Fig. 7 and Table 6. Reducing fuel consumption also means less emissions are caused by the solar PV-diesel system which has the lowest emission of $\mathrm{CO}_{2}$ and $\mathrm{NO}_{\mathrm{X}}$ as shown in Table 7.

\section{Discussions}

\section{Economic Cost}

The diesel-only system has a total NPC of $\$ 410,769$ (N $66,544,578)$, operating cost of $\$ 30,254(\mathrm{~N} 4,901,148)$, and initial cost of $\$ 63,760(\mathrm{~N} \mathrm{10,329,120)}$ while the PV-diesel has total NPC of $\$ 126,712$ (N 20,527,344),

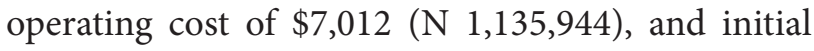
cost of $\$ 46,280(\mathrm{~N} 7,497,360)$ as shown in Fig. 6 and
7, respectively and Table 5. This system (proposed) saves $\$ 284,057 \mathrm{~N} 46,017,234$ to the health clinic when compared with the diesel-only system. Moreover, the operational life of the diesel only system is low (5.09 yrs), while in Hybrid system its diesel operational life is extended (23.4 yrs) as shown in Table 8.

\section{Electricity Production}

The existing system (diesel-only) produces 9,820

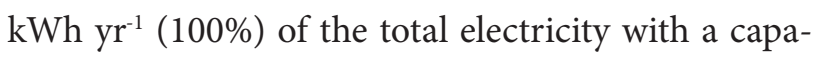
city factor of $44.8 \%$; whereas the proposed hybrid

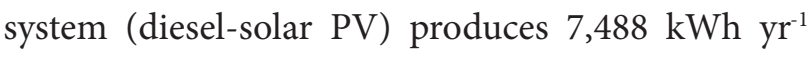

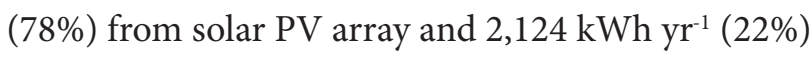
from diesel generator with a capacity factor of $9.70 \%$

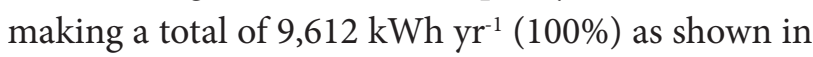
Figs. 8 and 9, respectively. The load demand is 7,082 $\mathrm{kWh} \mathrm{yr}^{-1}$, while the excess electricity from the existing system is $2738 \mathrm{kWh} \mathrm{yr}^{-1}$ and the proposed project has excess electricity of $2530 \mathrm{kWh} \mathrm{yr}^{-1}(26 \%)$ as shown in Table 6. The hybrid PV-diesel system is a renewable energy (PV) source with the capacity to supply $78 \%$ of the total electricity, as shown in Table 6 and Fig. 9.

\section{Environmental pollution}

The diesel-only system operates for 3,928 $\mathrm{h}_{\text {annum }}{ }^{-1}$ has a fuel consumption of $3,240 \mathrm{~L}^{\text {annum }}{ }^{-1}$ as shown in Table 8. It generates 8.533 tonnes of $\mathrm{CO}_{2}, 0.0211$ tonnes of CO, 0.00233 tonnes of UHC, 0.00159 tonnes of PM, 0.0171 tonnes of $\mathrm{SO}_{2}$, and 0.188 tonnes of $\mathrm{NO}_{\mathrm{X}}$ as shown in Table 7. In contrast, in the hybrid PV-diesel system, the diesel generator operates for $853 \mathrm{~h}$ annum $^{-1}$ and has a fuel consumption of 702 


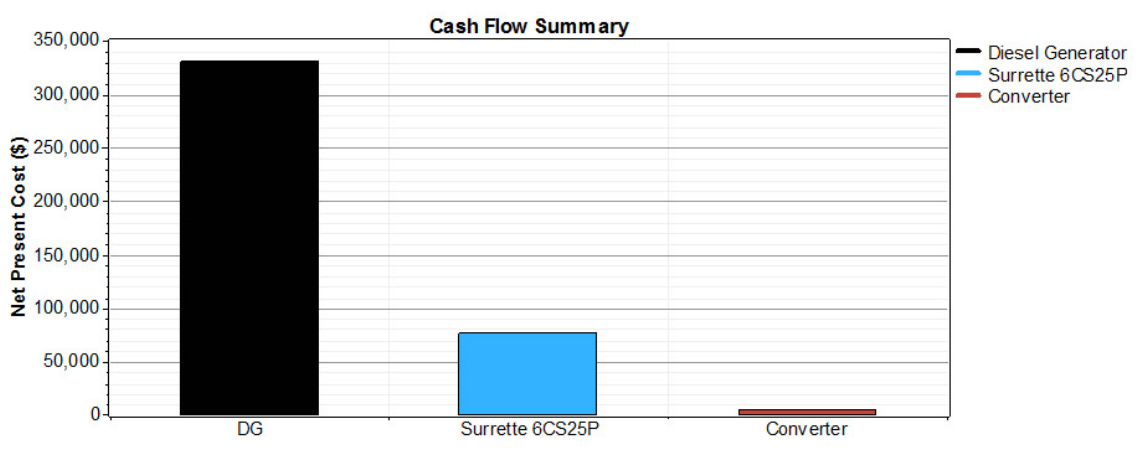

Figure 6 Net present cost of component of existing diesel only system.

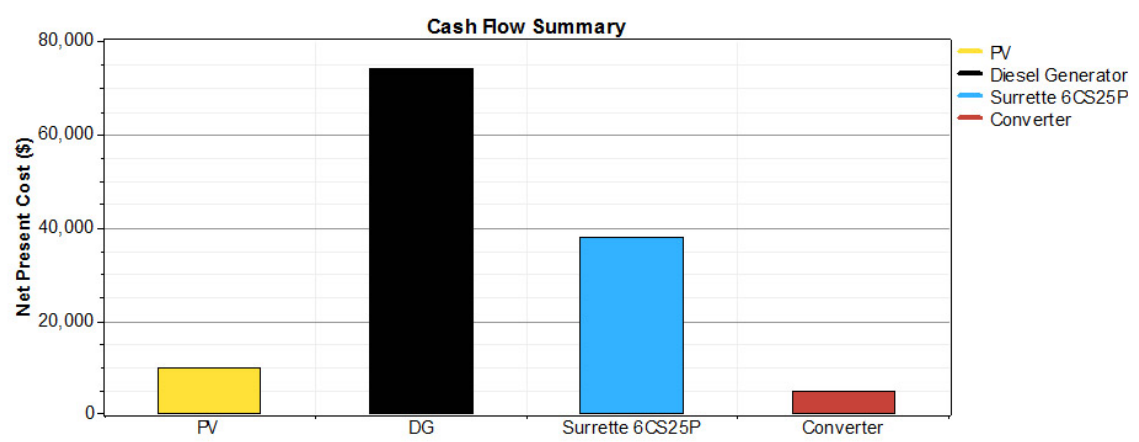

Figure 7 Net present cost of component of optimized hybrid diesel-solar PV energy system.

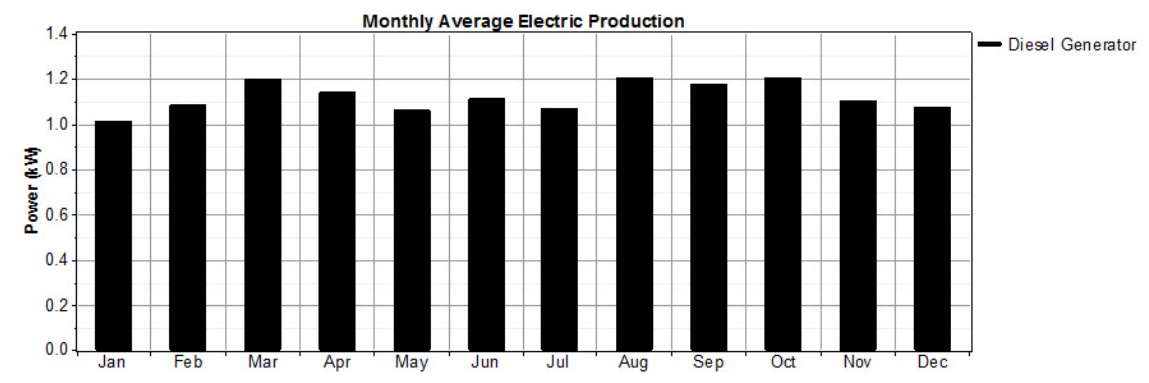

Figure 8 Electrical production of diesel only energy system.

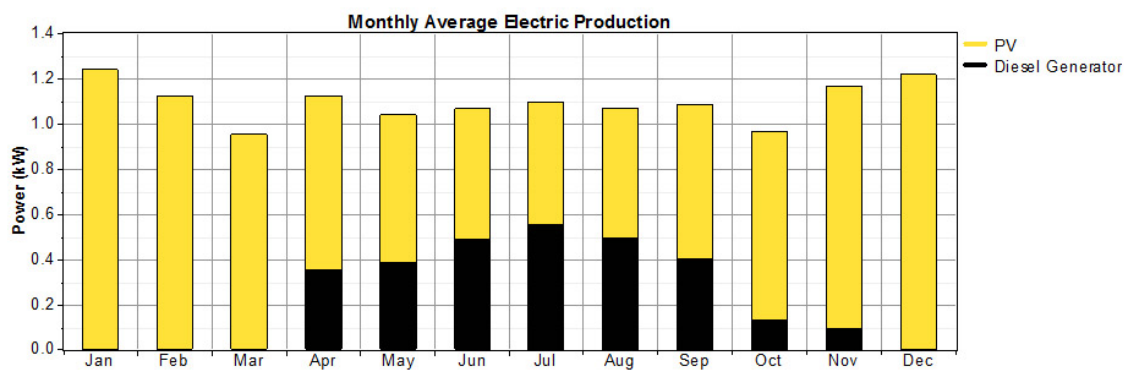

Figure 9 Electrical production of hybrid diesel-solar PV energy system.

$\mathrm{L}_{\text {annum }}{ }^{-1}$ as shown in Table 8 . This system emits 1.848 tonnes of $\mathrm{CO}_{2}, 0.00456$ tonnes of $\mathrm{CO}, 0.000505$ tonnes of UHC, 0.000344 tonnes of PM, 0.00371 tonnes of $\mathrm{SO}_{2}$, and 0.0407 tonnes of $\mathrm{NO}_{\mathrm{X}}$ annually into the atmosphere of the location of the health clinic as shown in Table 7. An approximate $78 \%$ decrease in each pollutant is noticed for a $78 \%$ renewable penetration into the existing diesel only power system. The 
Table 5 Comparison of Simulation results of Economic.

\begin{tabular}{|lcccc|}
\hline & \multicolumn{2}{c}{ Existing system diesel only } & \multicolumn{2}{c|}{ Proposed hybrid diesel-solar PV system } \\
\hline Parameter & Dollars(\$) & Naira(N) & Dollars(\$) & Naira(N) \\
\hline Initial Cost & 63,760 & $10,329,120$ & 46,280 & $7,497,360$ \\
Operating Cost & 30,254 & $4,901,148$ & 7,012 & $1,135,944$ \\
\hline Total NPC & 410,769 & $66,544,578$ & 126,712 & $20,527,344$ \\
\hline
\end{tabular}

Table 6 Comparison of simulation results of electricity production ( $\left.\mathrm{kWh} \mathrm{yr}^{-1}\right)$.

\begin{tabular}{|c|c|c|c|c|}
\hline \multirow{2}{*}{ Quantity } & \multicolumn{2}{|c|}{ Diesel only } & \multicolumn{2}{|c|}{ Diesel in hybrid system (diesel-solar PV) } \\
\hline & kWh yr-1 & $\%$ & kWh $\mathrm{yr}^{-1}$ & $\%$ \\
\hline \multicolumn{5}{|l|}{ Load Consumption } \\
\hline AC primary load & 7,082 & 100 & 7,082 & 100 \\
\hline \multicolumn{5}{|l|}{ Production } \\
\hline PV array & None & None & 7,488 & 78 \\
\hline Diesel Generator & 9,820 & 100 & 2,124 & 22 \\
\hline Total energy & 9,820 & 100 & 9,612 & 100 \\
\hline Excess electricity & 2738 & & 2530 & 26 \\
\hline
\end{tabular}

reduction in the quantity of different air pollutants for $78 \%$ renewable penetration compared to that diesel only are thus: 6.685 tonnes of $\mathrm{CO}_{2}, 0.01654$ tonnes of CO, 0.001825 tonnes of UHC, 0.001246 tonnes of PM, 0.01339 tonnes of $\mathrm{SO}_{2}$, and 0.1473 tonnes of $\mathrm{NO}_{\mathrm{X}}$. Moreover, from the fuel consumption, this hybrid system saves 2,538 Litres of fuel per year to the health clinic when compared with diesel only.

From an environmental impact perspective, an increase in the operational hours of a diesel generator brings about increase in the fuel consumption, as well an increase in GHG emission, whereas a reduction in the operational hours of diesel generator brings about reduction in the fuel consumption thereby a reduction in GHG emission.

Excess energy $=$ Total energy Production - Total energy Consumption

Excess energy $=(9,612-7,082) \mathrm{kWh} /$ year $=2,530$ $k W h /$ year.

The excess electricity occurs in the months of January, February, November, December and few days in March but occur most in January (as can be clearly seen in Fig. 10) when the energy generated by the solar energy system are at the highest (Table 3). This excess electricity of about $26 \%$ power supply is guaranteed in the location simulated in order to give room for future Clinic expansion or can be sold to nearby villages, factories, schools or facilities. The sale of this excess electricity will offer a promising approach for health facilities to finance operations and maintenance costs of the hybrid system.

From the optimization results the best optimal combination of energy system components $(2.5 \mathrm{~kW}$

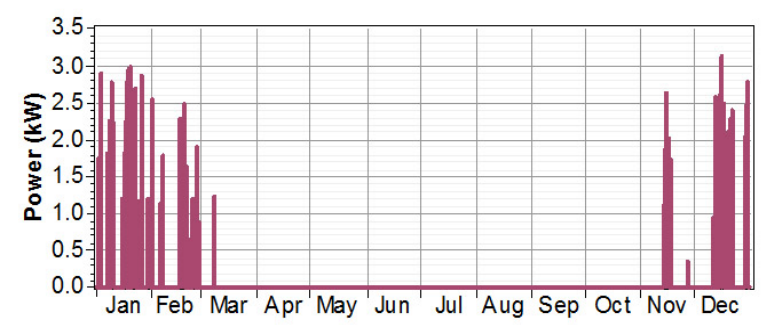

Figure 10 Excess electricity generated by the hybrid diesel/PV energy system. 
Table 7 Comparison of simulation results of emissions from existing and proposed system.

\begin{tabular}{|c|c|c|c|c|c|}
\hline \multirow{3}{*}{ Pollutant } & \multicolumn{4}{|c|}{ Emissions $\left(\mathrm{kg} \mathrm{yr}^{-1}\right)$} & \multirow{3}{*}{$\begin{array}{l}\text { Difference } \\
\text { (ton } \mathrm{yr}^{-1} \text { ) }\end{array}$} \\
\hline & \multicolumn{2}{|c|}{ Existing diesel only } & \multicolumn{2}{|c|}{$\begin{array}{c}\text { Proposed PV/diesel hybrid sys- } \\
\text { tem }\end{array}$} & \\
\hline & $\left(\mathrm{kg} \mathrm{yr}^{-1}\right)$ & $\left(\right.$ ton $\left.\mathrm{yr}^{-1}\right)$ & $\left(k g y^{-1}\right)$ & (ton $\mathrm{yr}^{-1}$ ) & \\
\hline Carbon dioxide & 8,533 & 8.533 & 1,848 & 1.848 & 6.685 \\
\hline Carbon monoxide & 21.1 & 0.0211 & 4.56 & 0.00456 & 0.01654 \\
\hline Unburned hydrocarbons & 2.33 & 0.00233 & 0.505 & 0.000505 & 0.001825 \\
\hline Particulate matter & 1.59 & 0.00159 & 0.344 & 0.000344 & 0.001246 \\
\hline Sulfur dioxide & 17.1 & 0.0171 & 3.71 & 0.00371 & 0.01339 \\
\hline Nitrogen oxides & 188 & 0.188 & 40.7 & 0.0407 & 0.1473 \\
\hline
\end{tabular}

Table 8 Comparison of simulation of existing system (diesel only) and proposed hybrid system (diesel-solar PV).

\begin{tabular}{|lcccc|}
\hline \multirow{2}{*}{ Quantity } & \multicolumn{2}{c}{ Diesel only } & \multicolumn{2}{c|}{ Diesel in hybrid system (diesel-solar PV) } \\
\hline Operational life & Value & Units & Value & Units \\
\hline Capacity factor & 5.09 & $\mathrm{yr}$ & 23.4 & $\mathrm{yr}$ \\
\hline Hours of operation & 44.8 & $\%$ & 9.70 & $\%$ \\
\hline Fuel consumption & 3,928 & $\mathrm{~h} \mathrm{yr}^{-1}$ & 853 & $\mathrm{~h} \mathrm{yr}^{-1}$ \\
\hline
\end{tabular}

diesel generator, $5 \mathrm{~kW}$ solar PV array, 24 Surrette 6CS25P Battery Cycle Charging, and a $19 \mathrm{~kW}$ converter) was determined for health facility located in rural area of Nkanu-West (Enugu State) as shown in Fig. 11.

\section{Conclusion}

It is determined that using a hybrid system to power health service facilities is far better than using the diesel-only power generation system, especially in areas where there is no utility power. The economic analysis of hybrid PV/diesel stand-alone systems carried out in this investigation verifies the predictions for the brilliant future of hybrid energy technology for health clinics in Nigeria. From the environmental analysis on pollutant emission, the hybrid PV/diesel system is preferred over diesel generators. The designed hybrid system minimizes the diesel operational hours, thus reducing fuel consumption, which significantly reduces pollution. If the diesel-only generator system is continued to be used by the health clinics in Nigeria, the $\mathrm{CO}_{2}$ generated in each clinic based on the simulation results will possibly cause an epidemic in the near future i.e global warming.

From the simulation results (costs and emissions), it has been demonstrated that the use of hybrid PV/ diesel system with battery could achieve significantly lower NPC and reduction of $\mathrm{CO}_{2}$ as compared to a standalone diesel system. Therefore, the suitability of a hybrid PV/diesel system with battery in health clinics was determined from the perspective of technical and economical analysis. It is concluded that, the hybrid PV/diesel system has a high potential for use in power generation at health clinics in Nigeria. 


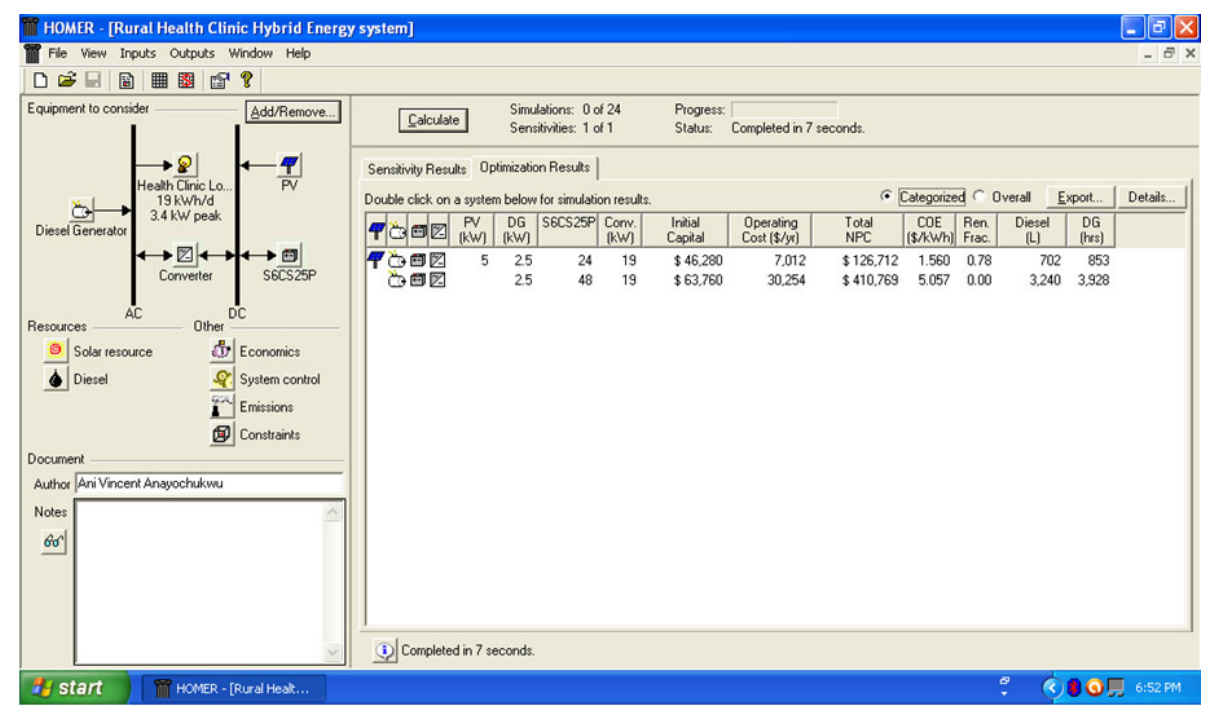

Figure 11 Overall optimization results of HOMER solutions.

\section{References}

Ani, V.A. and Emetu, A.N. (2013). Simulation and optimization of hybrid diesel power generation system for GSM base station site in Nigeria. Electronic Journal of Energy \& Environment. vol. 1, n ${ }^{\circ}$ 1. (In Press).

Ani, V.A. (2013). Simulation and optimization of stand-alone photovoltaic/diesel hybrid system for banking industry. International Journal of Energy Optimization and Engineering. (In Press).

Ani, V.A. and Nzeako, A.N. (2012). Energy optimization at GSM Base Station located at rural areas. International Journal of Energy Optimization and Engineering. vol. 1, $\mathrm{n}^{\circ}$ 3. (In Press)

Ashari, M. and Nayar, C.V. (1999). An optimum dispatch strategy using set points for a photovoltaic (PV)-diesel-battery hybrid power system. Solar Energy. vol. 66, no 1, 1-9.19.

Bala, E.J.; Ojosu, J.O. and Umar, I.H. (2000). Government policies and programmes on the

development of solar-PV sub-sector in Nigeria. Nigerian Journal of Renewable Energy. vol. 8, ${ }^{\circ} 1 \& 2$, 1-6.

Bernal-Agustín, J.L. and Dufo-López, R. (2009). Simulation and optimization of stand-alone hybrid renewable energy systems. Renewable and Sustainable Energy Reviews. vol. 13, no 8, 2111-2118.
Borowy, B.S. and Salameh, Z.M. (1994). Optimum photovoltaic array size for a hybrid wind/PV system. IEEE Transaction on Energy Conversion. vol. $9, n^{\circ} 3,482-488$.

Dufo-López, R. and Bernal-Agustín, J.L. (2005). Design and control strategies of PV-diesel systems using genetic algorithms. Solar Energy. vol. 79, n $1,33-46$.

Falade, T.S. (1995). Solving housing problems in Lokoja. B.Sc. Research Report. Department of Architecture, A.B.U. Zaria.

Faruk, N.; Ayeni, A.A.; Muhammad, M.Y.; Abdulkarim, A. and Moses, O. (2012). Hybrid power systems for cell sites in mobile cellular networks. Cyber Journals: Multidisciplinary Journals in Science and Technology, Journal of Selected Areas in Renewable and Sustainable Energy (JRSE). January Edition.

Giatrakos, G.P.; Tsoutsos, T.D.; Mouchtaropoulos, P.G.; Naxakis, G.D. and Stavrakakis, G. (2009). Sustainable energy planning based on a standalone hybrid renewable energy/hydrogen power system: application in Karpathos Island, Greece. Renewable Energy. vol. 34, 2562-2570.

Kamaruzzaman, S.; Ahmad, F.; Mohd. H.R.; Mohd, Y.S.; Mohammad, A.A.; Muhammad, Y.; Nowshad. A.; Lim, C.H. and Azami, Z. (2009). Optimization of a stand-alone wind/PV hybrid system to 
provide electricity for a house in Malaysia. Proceedings of the 4th IASME/WSEAS International Conference on ENERGY \& ENVIRONMENT.

Karakoulidis, K.; Mavridis, K.; Bandekas, D.V.; Adoniadis, P.; Potolias, C. and Vordos, N. (2011). Techno-economic analysis of a stand-alone hybrid photovoltaic-diesel-battery-fuel cell power system. Renewable Energy. vol. 36, 2238-2244.

Ojo, O. (2000). Fundamentals of physical and dynamic climatology. 1st ed., SEDEC Publ., Lagos, Nigeria.

Shaahid, S.M. and El-Amin, I. (2009). Techno-economic evaluation of off-grid hybrid photovoltaic-diesel-battery power systems for rural electrification in Saudi Arabia - a way forward for sustainable development. Renewable and Sustainable Energy Reviews. vol. 13, no 3, 625-633. doi: 10.1016/j.rser.2007.11.017.

Seeling-Hochmuth, G.C. (1998). Optimization of hybrid energy systems sizing and operation control. A Dissertation presented to the University of Kassel in Candidacy for the Degree of Dr.-Ing.

Wies, R.W.; Johnson, R.A.; Agrawal, A.N. and Chubb, T.J. (2005). Simulink model for economic analysis and environmental impacts of a PV with diesel-battery system for remote villages. IEEE Trans Power Systems. vol. 20, no 2, 692-700.

Wichert, B. (1997). PV-diesel hybrid energy systems for remote area power generation - a review of current practice and future developments. Re- newable and Sustainable Energy Reviews. vol. 1, $n^{\circ} 3,209-28$.

Yu, H.; Pan, J. and Xiang, A. (2005). A multi-function grid-connected PV system with reactive power compensation for the grid. Solar Energy. vol. 79, $\mathrm{n}^{\circ} 1,101-6$.

\section{Web Page}

Exchange rate for converting United States Dollar to Nigerian Naira: 1 USD $=161.49739$ NGN. Accessed on 07/17/2012, http://themoneyconverter. com/USD/NGN.aspx;

http://themoneyconverter.com/USD/NGN. aspx\#exchange-rates

HOMER (The Hybrid Optimization Model for Electric Renewables). Available from: http://www. nrel/gov/HOMER. Visited on 02/01/2012

NASA. (2012) http://eosweb.larc.nasa.gov/

Population Nigeria's over 167 million population: Implications and Challenges. 05 March 2012 14:46. http://www.population.gov.ng/ Last Updated on Monday,

Solarshopnigeria, (2012) http://www.solarshopnigeria.com/index.php/solar-pv-modules/solarworldmodules/sunmodule-sw-140-poly-r6a.html.

Nigerian Geography, (2012). Climate and Vegetation, http://www.nigeriahc.org.uk/aboutnigeria\# geography. Visited on 09/04/2013 